\title{
Quality of Source Water and Drinking Water in Urban Areas of Myanmar
}

\author{
Hiroshi Sakai, ${ }^{1}$ Yatsuka Kataoka, ${ }^{2}$ and Kensuke Fukushi ${ }^{3}$ \\ ${ }^{1}$ Department of Urban Engineering, The University of Tokyo, 7-3-1 Hongo, Bunkyo-ku, Tokyo 113-8656, Japan \\ ${ }^{2}$ Institute for Global Environmental Strategies, 2108-11 Kamiyamaguchi, Hayama, Kanagawa 240-0115, Japan \\ ${ }^{3}$ Todai Institute for Advanced Study, Integrated Research System for Sustainability Science, The University of Tokyo, \\ 7-3-1 Hongo, Bunkyo-ku, Tokyo 113-8654, Japan
}

Correspondence should be addressed to Hiroshi Sakai; h_sakai@env.t.u-tokyo.ac.jp

Received 16 April 2013; Accepted 27 May 2013

Academic Editors: M. Kumar and K. Kuroda

Copyright $\odot 2013$ Hiroshi Sakai et al. This is an open access article distributed under the Creative Commons Attribution License, which permits unrestricted use, distribution, and reproduction in any medium, provided the original work is properly cited.

Myanmar is one of the least developed countries in the world, and very little information is available regarding the nation's water quality. This report gives an overview of the current situation in the country, presenting the results of various water-quality assessments in urban areas of Myanmar. River, dam, lake, and well water sources were examined and found to be of generally good quality. Both As and $\mathrm{F}^{-}$were present in relatively high concentrations and must be removed before deep wells are used. Heterotrophic plate counts in drinking water were highest in public pots, followed by nonpiped tap water, piped tap water, and bottled water. Measures need to be taken to improve low-quality water in pots and nonpiped tap waters.

\section{Introduction}

Access to safe water is a significant issue in developing countries. According to a WHO report, around 780 million people globally do not have access to adequate water supply sources [1]. Additionally, 2.5 billion people do not have access to suitable sanitation facilities. Furthermore, about 2 million people die every year due to diarrheal diseases. Therefore, access to safe water is a crucial requirement in developing countries, where infrastructure is not always provided and often needs to be expanded. Due to the mismatches of urban planning and actual residential area, some areas must rely on inadequate private water supplies. This is a distinct issue in slum area and periurban areas.

Myanmar is a developing country in Southeast Asia. Even among the developing countries, Myanmar falls into the category of least developed countries by United Nations criteria [2]. The water infrastructure needs to be developed for the country's further economic development. However, very few water-quality data are currently available. To the best of our knowledge, only a single water-quality survey has been conducted [3]. That study reported water quality in Lake Inle in the northeastern part of the country. Some water-quality data for dams are provided on the webpage of the Water Environment Partnership in Asia [4] but only for limited quality parameters. To our knowledge, no other information has been reported, and the current water-quality and sanitation situations in Myanmar therefore remain unclear. We visited the country to perform a water-quality survey and assess the current situation with respect to water infrastructure. The survey was conducted in two urban areas, Yangon and Nay Pyi Taw, the former and current capital, respectively. This article reveals the water-quality and sanitation situations in Myanmar for the first time.

\section{Materials and Methods}

2.1. Study Area. We surveyed two urban areas, Nay Pyi Taw and Yangon. The city of Nay Pyi Taw became the capital in 2008; the city of Yangon was the previous capital. A survey of drinking-water sources and quality was undertaken. The details of the location of source waters are shown in Figure 1. In Nay Pyi Taw, source waters from a deep well and two dams were examined. In the Yangon area, environmental waters in lakes and rivers were examined. 


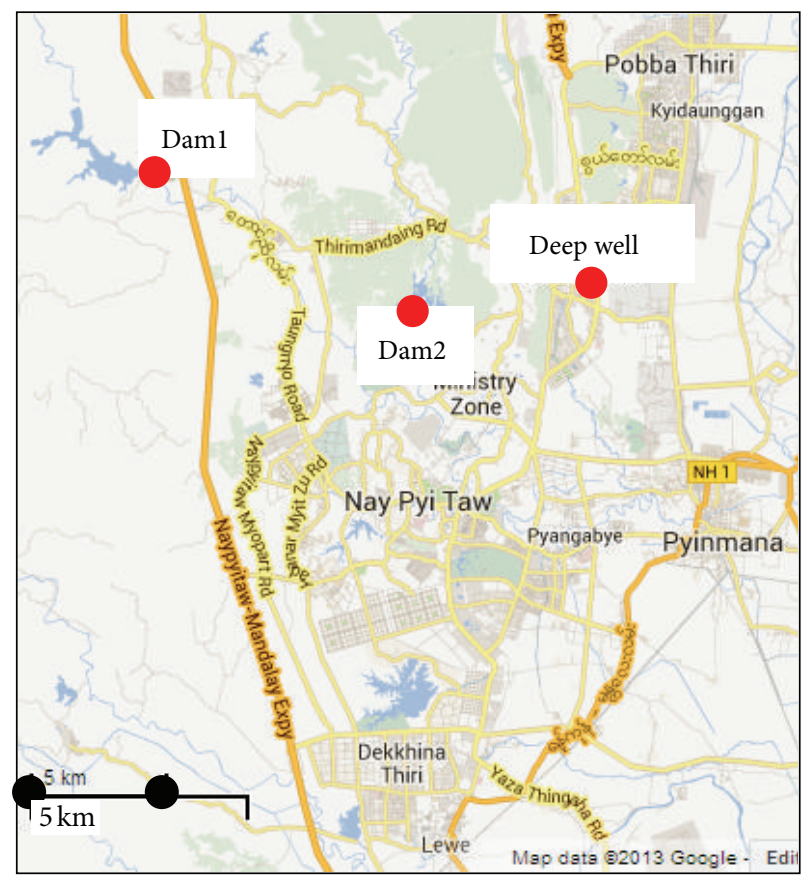

(a)

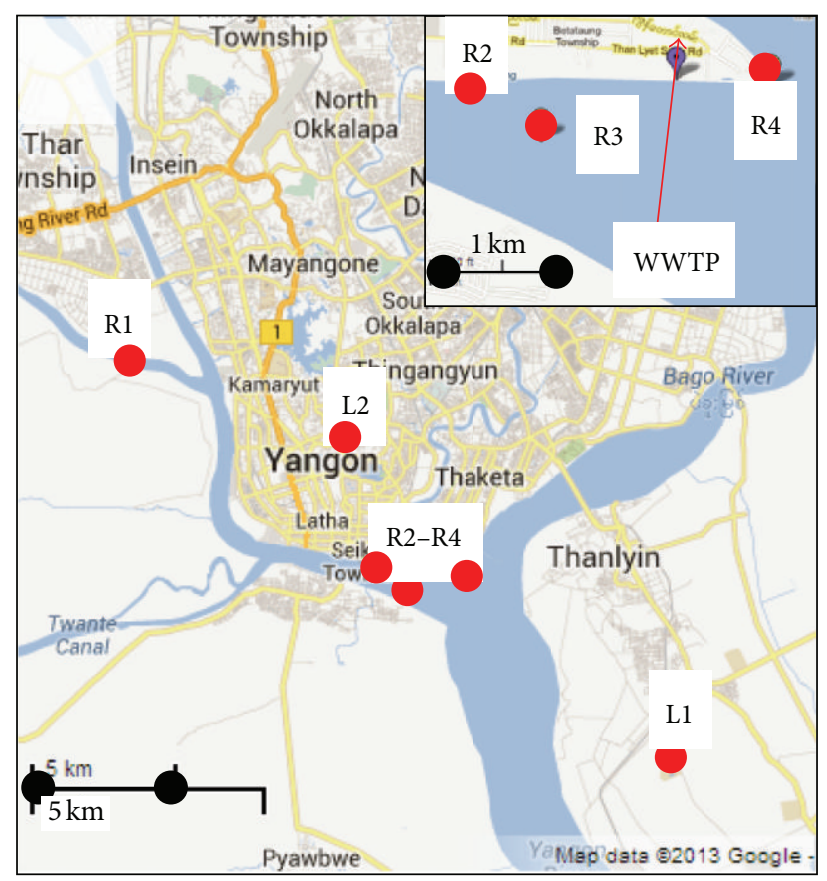

(b)

Figure 1: Maps of sampling locations in (a) Nay Pyi Taw and (b) Yangon.

TABLE 1: Summary of drinking-water samples.

\begin{tabular}{llc}
\hline Type & Description & Location \\
\hline \multirow{2}{*}{ Pot } & Pot A & Yangon \\
& Pot B & Suburban Yangon \\
\hline \multirow{3}{*}{ Nonpiped } & Pagoda A & Yangon \\
& Building D & Suburban Yangon \\
& After treatment & \\
& Before treatment & \\
Piped & Building A & Yangon \\
& Building B & Nay Pyi Taw \\
& Building C & Nay Pyi Taw \\
\hline \multirow{3}{*}{ Bottle } & Manufacturer A & - \\
& Manufacturer B & - \\
& Manufacturer C & - \\
\hline
\end{tabular}

Drinking water was collected from various sources including public pots, nonpiped taps, piped taps, and bottled waters, as shown in Table 1 . Three bottled waters $(500 \mathrm{~mL})$ from different companies were obtained commercially. Piped tap water was collected from three taps in Yangon and Nay Pyi Taw. Nonpiped tap water was collected at a pagoda and at another building (building D). In Myanmar, a pagoda is a meeting place for Buddhists, and complementary drinking water is provided. The tap water at the pagoda was provided by a nonpiped supply source. It was treated by a point-ofuse (POU) facility and then stored. Building D was situated outside Yangon city in an area that is not served by the Yangon City Development Committee (YCDC) tap-water service. The water supply system to the building was privately

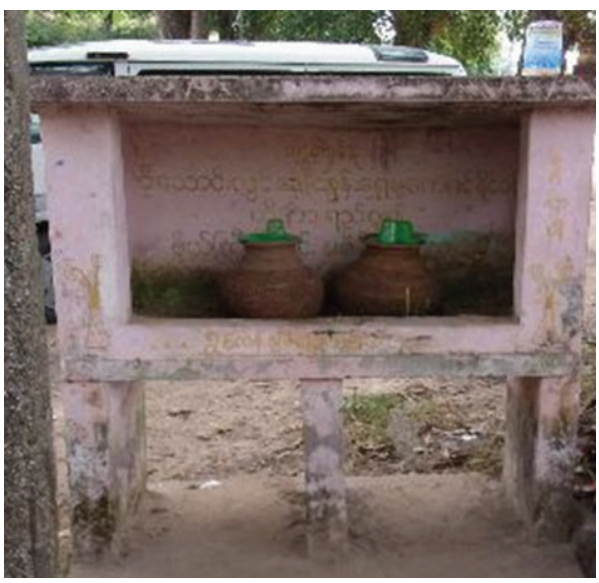

FIgURE 2: Roadside pots containing water for drinking.

operated by a POU facility that used a combination of a reverse osmosis (RO) membrane treatment and an ultraviolet (UV) disinfection system.

Drinking water was also collected from public pots located on the roadside (Figure 2). In the Yangon area, pots are filled with water, covered, and placed along the roadside for public drinking purposes. We collected samples from various pots and examined the water quality, with a focus on bacterial analysis.

\subsection{Measured Parameters}

2.2.1. Bacteria. The numbers of $E$. coli and total coliform bacteria and the heterotrophic plate counts (HPC) were 


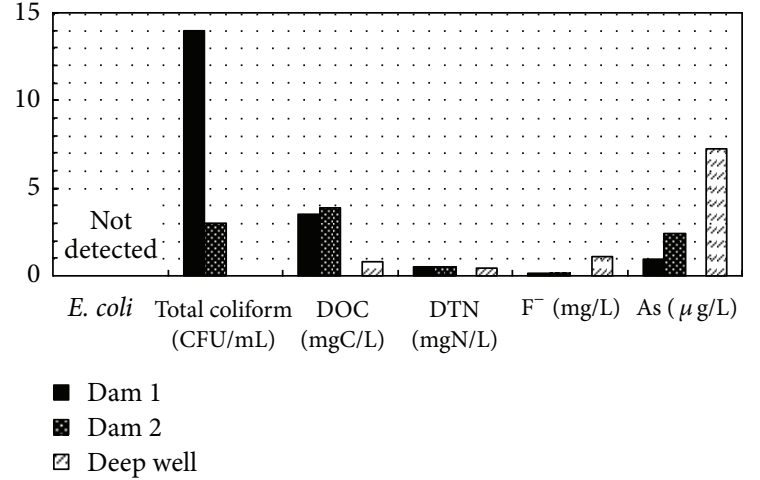

Figure 3: Comparison of water quality in dams and a deep well water at Nay Pyi Taw.

determined using a commercial kit (Petrifilm, 3M, USA) at each site. E. coli and total coliform bacteria were incubated at $37^{\circ} \mathrm{C}$ for 24 hours, and $\mathrm{HPC}$ was incubated at $37^{\circ} \mathrm{C}$ for 48 hours. The validity of this kit has been confirmed $[5,6]$, and it showed high correlations for E. coli and total coliform. High correlations were also reported for HPC, although small differences can arise with different incubation conditions [7].

2.2.2. Chemical Parameters. Dissolved organic carbon (DOC), dissolved total nitrogen (DTN), and anions were measured with a TOC analyzer (TOC-L, Shimadzu). Anion concentrations $\left(\mathrm{F}^{-}, \mathrm{Cl}^{-}, \mathrm{Br}^{-}, \mathrm{NO}_{2}{ }^{-}, \mathrm{NO}_{3}{ }^{-}, \mathrm{PO}_{4}{ }^{-}\right.$, and $\mathrm{SO}_{4}{ }^{-}$) were determined by ion chromatography (IC-861, Metrohm) after filtration through a $0.45 \mu \mathrm{m}$ polytetrafluoroethylene (PTFE) membrane.

2.2.3. Heavy Metals. Dissolved metals were analyzed by ICPMS (7500 Series, Agilent) after filtration through a $0.45 \mu \mathrm{m}$ PTFE membrane.

\section{Results and Discussions}

3.1. Source Water Quality in Nay Pyi Taw. Water quality parameters in two dams and a deep well in Nay Pyi Taw were examined and compared. A summary of the results, shown in Figure 3, indicates generally good water quality. No $E$. coli was detected in $1 \mathrm{~mL}$ samples at all locations, indicating good bacterial water quality. Total coliform levels were 14 and $3 \mathrm{CFU} / \mathrm{mL}$ at the two dams. These values are close to $10 \mathrm{CFU} / \mathrm{mL}$, which is the "class A" Japanese environmental standard for lake water [8]. The DOC was $3.5 \mathrm{mg} / \mathrm{L}$ at Dam 1 and $3.0 \mathrm{mg} / \mathrm{L}$ at Dam 2, and it was $0.8 \mathrm{mg} / \mathrm{L}$ in the deep well. Values of DOC at the two dams were acceptable for water sources, considering that $3 \mathrm{mg} / \mathrm{L}$ of TOC in finished water has been adopted as a drinking-water standard in Japan [9]. A previous study had reported about $30-50 \mathrm{mg} \mathrm{C} / \mathrm{L}$ of TOC in Lake Inle [3]. Compared with the results for Lake Inle, these two dams have a much better water quality.

Two important observations were made with regard to the deep well water quality. Fluoride ion levels were $1 \mathrm{mg} / \mathrm{L}$, which is close to the $1.5 \mathrm{mg} / \mathrm{L} \mathrm{WHO}$ guideline value [10]. The As
TABLE 2: Bacterial water quality in Yangon.

\begin{tabular}{lcccccc}
\hline Location & R1 & R2 & R3 & R4 & L1 & L2 \\
\hline Total coliform $(\mathrm{CFU} / \mathrm{mL})$ & 52 & 820 & 32 & 38 & 10 & 110 \\
E. coli $(\mathrm{CFU} / \mathrm{mL})$ & 20 & 510 & 15 & 16 & $<1$ & 2 \\
\hline
\end{tabular}

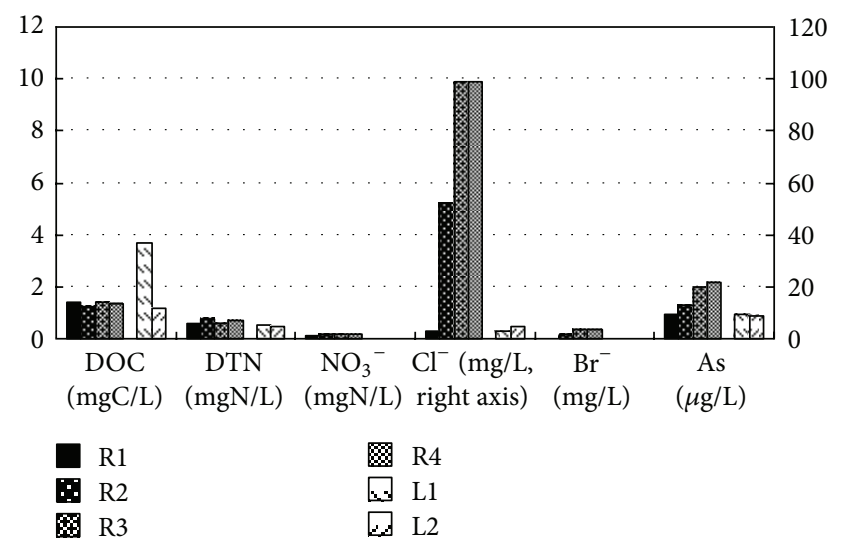

FIGURE 4: Comparison of water quality in rivers and lakes at Yangon.

level was $7.9 \mu \mathrm{g} / \mathrm{L}$, which is also close to the WHO guideline value of $10 \mu \mathrm{g} / \mathrm{L}$. Therefore, adequate water treatment must be provided before the well can be used as a drinking-water source. Overall, the water quality in the two dams and the deep well could be considered fair, and the water could be used for drinking with appropriate treatment.

3.2. Environmental Water Quality in Yangon. Environmental water quality was also surveyed in the Yangon region. The results of bacterial parameters are shown in Table 2. The Japanese standard for total coliform levels in river water is $0.5 \mathrm{CFU} / \mathrm{mL}$ for class $\mathrm{AA}, 10 \mathrm{CFU} / \mathrm{mL}$ for class $\mathrm{A}$, and $50 \mathrm{CFU} / \mathrm{mL}$ for class B [8]. River waters in Yangon were found to be close to the class B standard, indicating that they can be used for drinking after advanced treatment. Among the sampling points on the Yangon River, R2 was located on the left riverbank, whereas R3 and R4 were located in the center of the river. The total coliform value was highest at R2 on the left riverbank, which was closest to urban activity. There was also a discharge from a wastewater treatment plant on the left riverbank, which would have contributed to the larger number of total coliform recorded at $\mathrm{R} 2$.

$\mathrm{L} 1$ and L2 are recreational lakes in the Yangon region. At L1, E. coli was not detected in $1 \mathrm{~mL}$ samples, whereas the level was $2 \mathrm{CFU} / \mathrm{mL}$ at L2. Total coliform was also high, with $110 \mathrm{CFU} / \mathrm{mL}$ at L2. A previous report indicated total coliform levels of $18-137 \mathrm{CFU} / \mathrm{mL}$ in Lake Inle [3]. Considering these numbers, L2 was not suitable as a drinking-water source.

The chemical water-quality parameters are summarized in Figure 4. In river water samples, the DOC was less than $3 \mathrm{mg} \mathrm{C} / \mathrm{L}$, which satisfies the Japanese drinking-water-quality standard [9]. Levels of the $\mathrm{Cl}^{-}$ion tended to increase downstream. The levels of $\mathrm{Br}$ ion and As displayed a similar trend, although the decrease was not as marked. In contrast to 


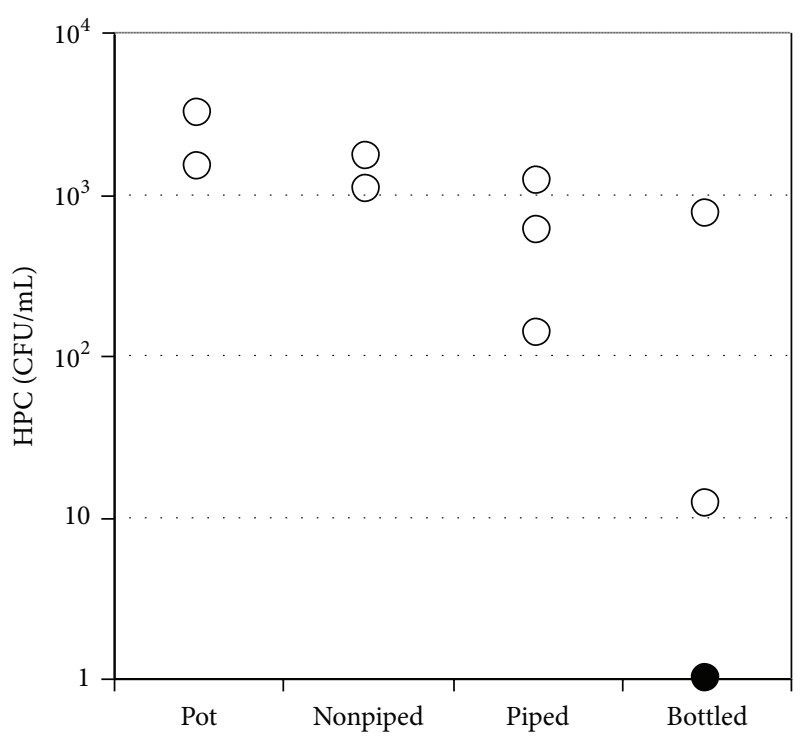

Figure 5: Heterotrophic plate count for potable water.

the elemental measurements, DOC, DTN, and nitrate were stable along the river flow. It was therefore assumed that the sources of $\mathrm{Cl}^{-}, \mathrm{Br}^{-}$, and As were different from those of carbon and nitrogen.

Samples from L1 and L2 had good water quality with regard to chemical parameters, except for high DOC in L1. Overall, lake and river waters were good in terms of their chemical parameters, but the levels of bacterial contamination needed improvement.

3.3. Drinking-Water Quality. Potable drinking-water quality was surveyed for various water sources in Myanmar including (i) public pots, (ii) piped water supply in Yangon and Nay Pyi Taw, (iii) nonpiped water supply, and (iv) bottled water.

For bacterial water quality, E. coli was not detected in $1 \mathrm{~mL}$ water samples from any water source. However, there was a clear trend in the HPC, as shown in Figure 5. Pot water had HPC levels of 3200 and $1500 \mathrm{CFU} / \mathrm{mL}$. In nonpiped tap water, the HPC level was 1700 and $1170 \mathrm{CFU} / \mathrm{mL}$, and, in piped tap waters, the HPC was 140,600 , and $1200 \mathrm{CFU} / \mathrm{mL}$. Of the three bottled waters examined, HPC was detected in two bottles at 760 and $12 \mathrm{CFU} / \mathrm{mL}$, but HPC was not detected in the other bottled water sample. HPCs have various incubation conditions [11], and different incubation conditions produce different values. The Japanese government has adopted a value of $2000 \mathrm{CFU} / \mathrm{mL}$ as a water-quality standard for HPC by incubation at $20^{\circ} \mathrm{C}$ for 7 days [9]. This is equal to about $740 \mathrm{CFU} / \mathrm{mL}$ by incubation at $37^{\circ} \mathrm{C}$ for 2 days in Petrifilm, which we used in our preliminary investigation (unpublished data). From these results, we concluded that water from all pots, all nonpiped taps, one piped tap, and one bottled water exceeded the converted value of the Japanese drinking-waterquality standard and may not be suitable for drinking.

As shown in Figure 5, HPC was highest in the pots, followed by nonpiped taps, piped taps, and bottled waters. Nonpiped water was surveyed at two taps, at a pagoda and at

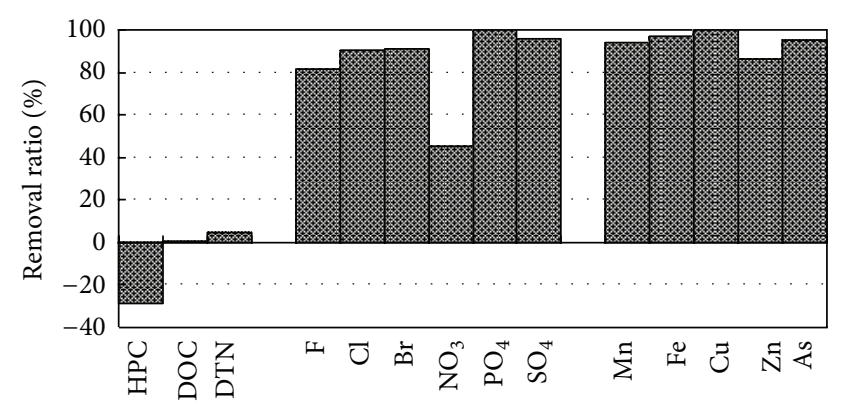

FIGURE 6: Removal ratio for a point-of-use (POU) facility.

a building outside the YCDC tap water service area. At those taps, water was supplied after treatment by POU facilities.

Piped water was surveyed at two buildings in Nay Pyi Taw and at one building in Yangon. Piped water supplies contained some residual chlorine: $0.01 \mathrm{mg} / \mathrm{L}$ at two taps in Nay Pyi Taw and $0.03 \mathrm{mg} / \mathrm{L}$ at a tap in Yangon. At a tap in Yangon, chlorine was present entirely as free chlorine. This residual chlorine may have contributed to the upkeep of water quality in the piped water supply.

It is interesting to note the water-quality distribution in bottled waters, with one bottled water supply having worse water quality than two piped taps. This probably results from the source water quality and the treatment efficiency of different bottled water companies. Other water-quality parameters were also monitored, including As and $\mathrm{F}^{-}$. All measured items satisfied the Japanese drinking-water-quality standards [9].

3.4. Treatment Efficiency of a POU Facility. We investigated the performance of a POU facility at a building in Yangon, which was situated outside the YCDC piped water supply area. The water source was ground water, which was treated by an RO membrane followed by UV disinfection. The removal ratios of bacteria (HPC), carbon and nitrogen, anions, and metals are shown in Figure 6. The listed heavy metals were removed with high efficiency. Anions were also removed with high efficiency except for nitrate, for which only a $45 \%$ removal was achieved. Because UV treatment does not remove anions and metals, these elements were removed by the $\mathrm{RO}$ membrane.

In contrast, DOC and DTN removal was very low: $1 \%$ DOC and 5\% DTN. The DOC and DTN contents of raw water were $0.55 \mathrm{mg} \mathrm{C} / \mathrm{L}$ and $0.23 \mathrm{mg} \mathrm{N} / \mathrm{L}$, respectively. Considering the removal of anions and metals, the RO membrane would have worked well. A possible explanation is that most organic matter and nitrogen in raw water have a very small molecular weight and can pass through the RO membrane. Further investigation of the molecular weight distribution would confirm this assumption.

It is noteworthy that the bacterial removal ratio was negative. Considering the removal of anions and metals, bacteria could be removed by the RO membrane treatment. UV treatment also contributes to the suppression of bacterial activity, but UV treatment has no residual effect. Therefore, bacterial regrowth may occur in a storage tank after 
UV treatment. UV treatment has a high potential to be installed in POU facilities because of its ease of handling and maintenance. Maintaining bacterial water quality after UV treatment is an important issue outside the piped water supply area.

\section{Conclusion}

This study investigated the water quality in urban areas of Myanmar and produced an overview of the current situation. River, dam, lake, and well water samples were examined and found to be of generally good quality. As and $\mathrm{F}^{-}$were present at relatively high concentrations and must be removed before deep wells can be used. Heterotrophic plate counts in drinking water were highest in pots, followed by nonpiped tap water, piped tap water, and bottled water samples. Measures need to be taken to improve the poor water quality in pots and nonpiped taps.

\section{Acknowledgments}

The authors would like to express appreciations to Dr. $\mathrm{Mu} \mathrm{Mu}$ Than and Dr. Kyi Kyi Lwin for their kind supports for water sampling. This paper was prepared with a partial support by MEXT through Green Network of Excellence (Eco-Health Project).

\section{References}

[1] WHO, Progress on Drinking Water and Sanitation, World Health Organization, Geneva, Switzerland, 2012.

[2] United Nations, "Least developed countries," 2012, http://www .unohrlls.org/en/ldc/25/.

[3] F. Akaishi, M. Satake, M. Otaki, and N. Tominaga, "Surface water quality and information about the environment surrounding Inle Lake in Myanmar," Limnology, vol. 7, no. 1, pp. 57-62, 2006.

[4] Water Environment Partnership in Asia, "State of water environmental issues, Myanmar," 2003, http://www.wepa-db.net/ policies/state/myanmar/myanmar.htm.

[5] V. Beloti, J. A. de Souza, M. D. A. F. Barros et al., "Evaluation of Petrifilm EC and HS for total coliforms and Escherichia coli enumeration in water," Brazilian Journal of Microbiology, vol. 34, no. 4, pp. 301-304, 2003.

[6] H. Schraft and L. A. Watterworth, "Enumeration of heterotrophs, fecal coliforms and Escherichia coli in water: comparison of 3M Petrifilm plates with standard plating procedures," Journal of Microbiological Methods, vol. 60, no. 3, pp. 335-342, 2005.

[7] S. A. Mueller, J. E. Anderson, B. R. Kim, and J. C. Ball, "Comparison of plate counts, Petrifilm, dipslides, and adenosine triphosphate bioluminescence for monitoring bacteria in coolingtower waters," Water Environment Research, vol. 81, no. 4, pp. 401-406, 2009.

[8] Ministry of Environment, "Environmental quality standards for water pollution," 2013, http://www.env.go.jp/en/water/wq/ wp.pdf.

[9] Ministry of Health, Labour, and Welfare, "Water quality standards," 2013, http://www.mhlw.go.jp/english/policy/health/ water_supply/4.html.
[10] WHO, Guidelines for Drinking-Water Quality, World Health Organization, Geneva, Switzerland, 4th edition, 2011.

[11] J. Bartram, J. Cotruvo, M. Exner, C. Fricker, and A. Glasmacher, Heterotrophic Plate Counts and Drinking-Water Safety, International Water Association, London, UK, 2003. 

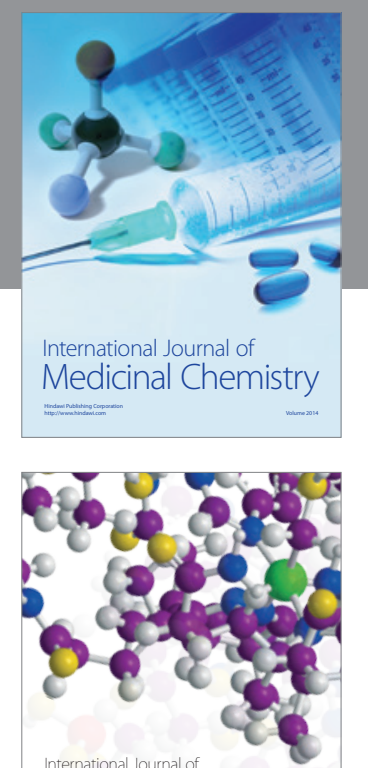

\section{Carbohydrate} Chemistry

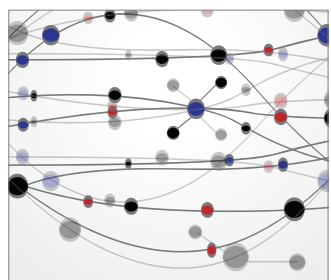

The Scientific World Journal
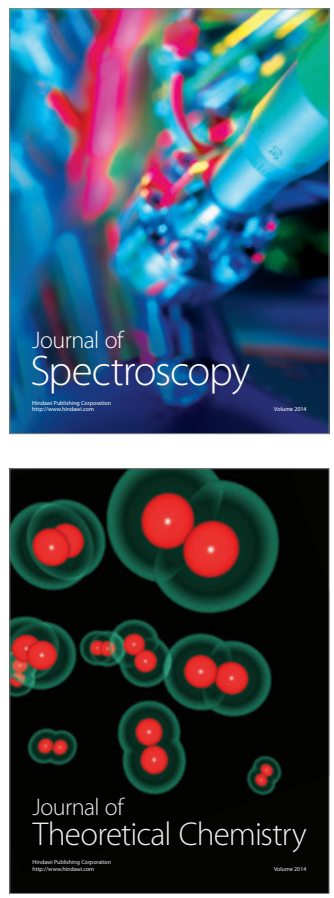
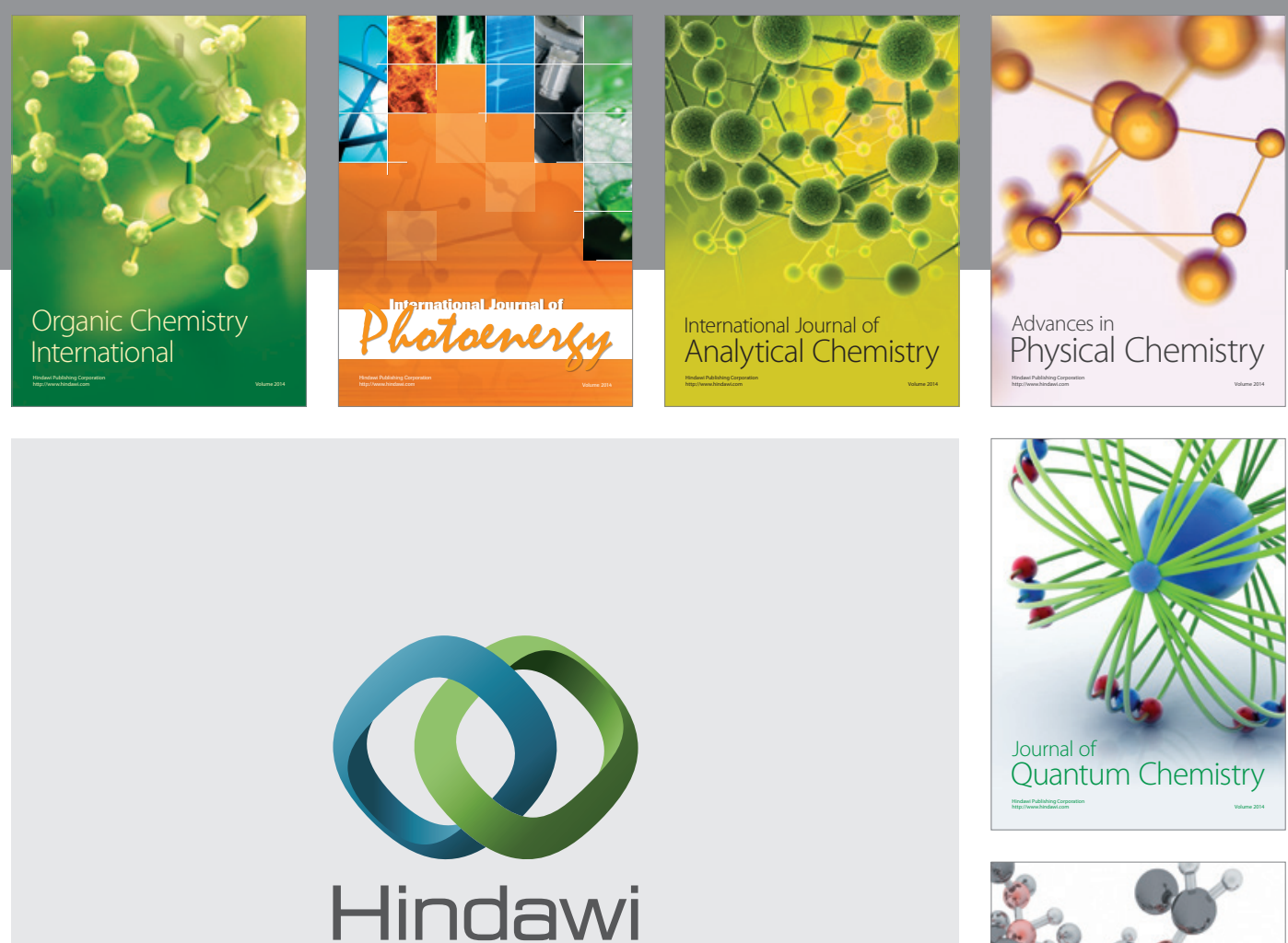

Submit your manuscripts at

http://www.hindawi.com

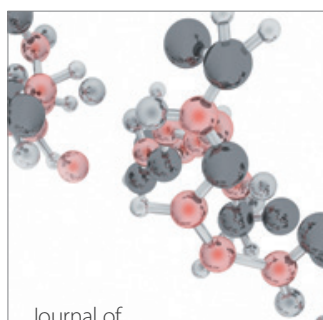

Analytical Methods

in Chemistry

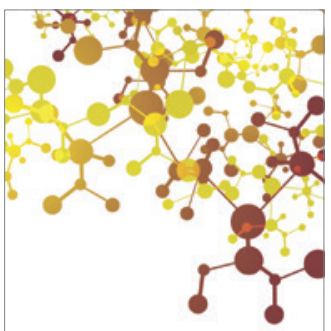

Journal of

Applied Chemistry

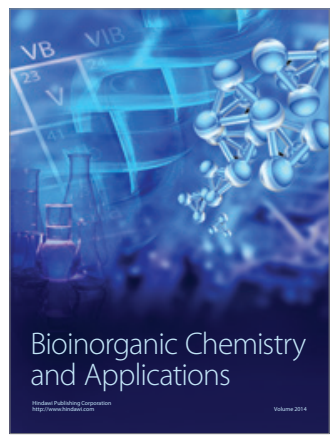

Inorganic Chemistry
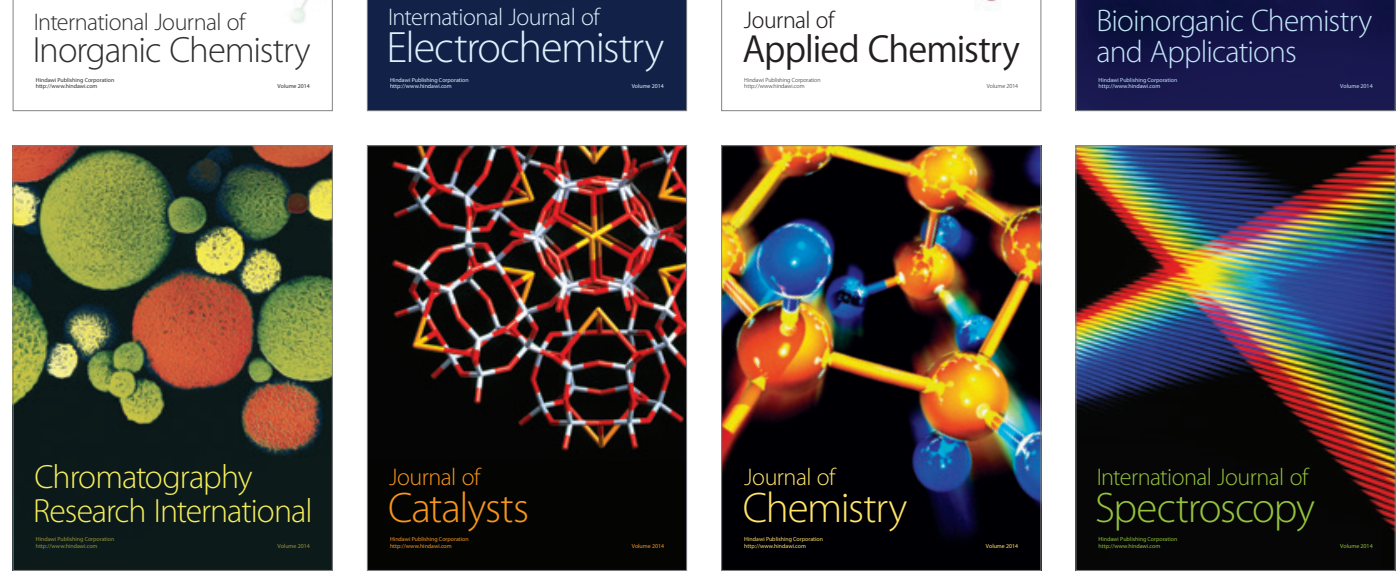